\title{
The Consequences of the Identity Theft Fear in the Sport Products Online Shopping From the Perspective of Physical Education Students
}

\author{
${ }^{1}$ Maryam Khani, ${ }^{1}$ Zynalabedin Fallah*, ${ }^{1}$ Taher Bahlakeh, ${ }^{2}$ Nasser Bai \\ ${ }^{1}$ Department of Physical Education and Sport Science, Gorgan Branch, Islamic Azad University, Gorgan, \\ Iran. ${ }^{2}$ Department of Physical Education and Sport Science, Azadshahr Branch, Islamic Azad University, \\ Azadshahr, Iran.
}

Submitted 24 February 2020; Accepted in final form 31 April 2020.

\begin{abstract}
Background. Today, online shopping has become one of the most important components of modern marketing that had both positive and negative consequences for customers. Objectives. The purpose of present research was to study the consequences of fear of identity theft in sport products online shopping from the perspective of physical education students. Methods. The present study is a descriptive-correlational survey and its statistical population includes all physical education students of Golestan province universities that 384 students were selected through available sampling as the statistical sample of the study. To collec research data, Hille et al (2015) fear of identity theft questionnaire, Chen et al (2015) perceived risk questionnaire and Chou \& Hsu (2016) willingness to online shop questionnaire were used. Validity of the questionnaires was verified by 8 masters of sport management and internal consistency of questionnaires by using Cronbach's alpha was determined respectively $0.86,0.78$ and 0.81 . To analyze the data and identify the effects of research variables, structural equation modeling was used in the PLS software. Results. The result showed that fear of losing money in the customer has a positive and significant effect on perceived risk. The effect of fear of credit damage in the customer on perceived risk was positive and significant. Finally, the results showed that the effect of perceived risk on the physical education students' willingness to online shopping was negative and significant. Conclusion. According to the results of the study, increasing awareness of physical education students about the selling rules of sports websites and increasing the security of sport products websites in order to reduce consumers' fears and concerns are suggested.
\end{abstract}

\section{KEYWORDS: Sports Products, Identity Theft, Online Shopping, Perceived Risk, Willingness to Shop.}

\section{INTRODUCTION}

The growth of information and communication technology today is significant, and the profound effects of this technology can be seen in almost every aspect of people's daily lives, such as banking, recreation and entertainment and business interactions (1). The development of new communication technologies has also affected the business environment of organizations and companies and, the presence of technologies such as the Internet has dramatically changed traditional marketing processes, and terms such as e-business have become an important part of the marketing literature (2). Along with these changes, online stores are replacing traditional stores and a large part of customers' shopping is performed online (3); it is

*. Corresponding Author:

Zynalabedin Fallah, Ph.D

E-mail: Fallahz586@gmail.com 
estimated that in 2017 alone, one billion six hundred and sixty million people worldwide have had at least one online purchase experience (4). Similarly, the results of a survey conducted in twenty-five different countries showed that, on average, $54 \%$ of daily, weekly and monthly customer purchases are done online (5). On the other hand, it is predicted that the turnover of ecommerce worldwide will reach more than four trillion dollars by 2020 , indicating the importance and development of e-business in today's world (6). The development of e-business has not been confined to a particular industry, and in the last few years, as in other industries, online sales of goods and services in the sports industry have also increased exponentially; as of 2016, online retailers in the United States accounted for $14.8 \%$ of total online sales of sport products and services and the average online sales of sport products in the country have increased by 31 percent since 2011 (7). South Korea's National Statistics Center report for 2016 also showed that $10.6 \%$ of the online sales of the country were related to apparel and sportswear and $3.8 \%$ to online sales of sports and recreational equipment (8). These figures represent the importance and position of ecommerce in the sports industry in different countries.

Nowadays, online purchase has been increasing for a variety of reasons, such as the development of the Internet platform, increasing the awareness and knowledge of consumers about e-commerce and achieving the numerous benefits of this type of shopping by the customers (9). In such conditions, online product and service providers strive to increase customers' willingness to repurchase by utilizing various methods such as enhancing the quality of ecommerce, diversified pricing, extensive advertising and after-sales service while satisfying them (10); because, encouraging and motivating online consumers to increase repeat purchasing can be considered as an important factor to gain competitive advantage and sustainable performance in e-business (11). On the other hand, as e-commerce grows, the challenges and concerns of manufacturers and customers have also increased and cybercrime in e-business has increased in recent years (12). Increasing these crimes can cause consumers to worry about online identity theft and have a negative impact on customer shopping behaviors (13) and (14). Online identity theft, which is often conducted by cybercriminals in cyberspace, has been defined as the illegal use of other persons' identities (name, surname, date of birth, credit card number, address of residence, etc.) to commit financial and non-financial fraud on the Internet (15). Reyns (2013) also states that identity theft is an act in which fraudsters use other people's personal information without their consent to pursue their personal gain. This can cause harm to the victim (16). Considering the importance of the subject, Hille et al. (2015) in a research developed a questionnaire for identity theft which included two components of fear of losing money in the customer and fear of credit damage in the customer. The fear of losing money in the customer indicates the concern for financial loss which may be caused by the loss of customer financial information such as card information or bank accounts in online purchase. Fear of credit damage in the customer also reflects the customer's concern about the use of personal information for the purpose of impersonating the customer, which can lead to credit damage in the customer in the community (12). With increasing negative and threatening consequences of online business identity theft, there have been many legal efforts to prevent this malicious activity on the Internet, but statistics show that online theft is on the rise (17). In the United States alone, more than 34.2 million people over the age of 16 have been victims of online theft at least once, and 70 percent of Internet users in the country are more concerned about online identity theft that physical theft. Also, $8.8 \%$ of the adult populations in the UK have been subjected to cyber identity theft at least once. On the other hand, the average damage to online customers by identity theft in the United States in 2012 was estimated at 2 billion and eighty-three million dollars (18), this has implications for victims such as emotional distress (such as depression and anxiety), physical consequences (such as headaches and hypertension) and disruption of life (lost time at work) (19).

Many researchers believe that cybercrime, such as identity theft, is an important part of the potential risks of e-business and that these can have many negative consequences for customers and sellers (20). Holtfreter et al (2015) note that identity theft is one of the most important challenges facing online commerce and that fear of identity theft can diminish customer trust (18). Fear of identity theft can also increase the 
perceived risk of online purchase among customers and affect their intention for shopping (21). Consumers are expected to feel a certain degree of risk when shopping online that, this has led to the fact that online purchase is still known as a risky activity in the e-market (22). Compared to traditional shopping, online purchase has more risks; this is because it is more difficult to evaluate the product and issues related to purchase security and privacy in this type of shopping (23). Perceived risk also plays an important role in shaping the customer's attitude towards the product or service, evaluating them and setting consumer buying goals (24). Kim and Lennon (2013) believe that perceived risk has a negative effect on online purchase intention in the customer, and the higher perceived risk will lead to less purchase intention (25). Yu (2018) states that fear of losing identity information, damage to personal credit and fear of losing money were among the causes of concern for online customers and, despite widespread efforts to decrease these concerns by sellers and legal authorities, the presence of these factors can increase perceived risk in online purchase and reduce the online purchase intention for customers (26). However, Han and Kim (2017) believe that fear of losing identity information and fear of losing money were not the only perceived risk factors in customers and product-related risks, time-related risks, social risks, and psychological risks also play an important role in customers' online buying behaviors (27).

Along with the rise of destructive and damaging practices in the field of e-business such as identity theft, research in this field has been increasingly conducted to understand the causes and consequences (18). Saleh (2013) in a study on 217 customers who had online purchase experience, concluded that fear of online identity theft diminishes customer trust in sellers (28). Riesig and Haltfreiter (2013) in a study of elderly people found that a large number of financial frauds on elderly people in various product purchases were done through both telephone and email shopping (29). Golladay \& Holtfreter (2016) examined the effects of identity theft in a study. The results showed that identity theft reduces mental health and physical health of victims (19). Jordan et al. (2018) in a study examined the consequences of fear of identity theft and, they found that fear of credit damage and fear of losing money had a positive effect on customer perceived risk and, perceived risk had a negative effect on the online purchase intention in customers (21). Yu (2018) found in a survey of Amazon online store customers that giving confidence to the customers in reimbursement for any problems, including fraud, had a positive effect on their purchase intention (26). Brands \& Van Wilsem (2019) in a study examined the effect of fear of losing money on the behaviors of customers who had online purchase experience. The results of this study showed that consumers' perception of fear of losing financial resources increases their protective behaviors and decreases their online buying behavior (30).

In the last few years, the number of domestic sellers and providers of sport products has been increasing, which has created an opportunity to develop and enhance the interaction between manufacturers and buyers of these products. On the other hand, with the extension of the Internet and the increasing importance of e-commerce and the development of online stores that exist as websites, Telegram channels, Instagram pages, sales apps, etc., the importance of selling sport products in this way is clear (31). However, creating the appropriate infrastructure for the development of e-commerce in the field of sport products and services is a subject that needs more attention; because in the future a large part of customer purchases will be done online and a positive customer experience in this type of shopping can be a factor for obtaining competitive advantage. Along with the positive benefits, online purchase also raises concerns for consumers of sporting goods, perhaps one of the most important of which is consumers' fear of the security of this type of purchase. Since the online purchase experience is different from the traditional shopping, increasing the knowledge and awareness of sports customers is of the benefits of online purchase and creating a safe environment for online shoppers in a way to decrease the concerns about issues such as fear of losing information and money to a minimum, can positively change the attitude and outlook of customers and encourage them to repeat online buying behavior, which will benefit both customers and online sellers. However, so far no research has been conducted on the fear of identity theft in online purchase and its consequences from the perspective of sports customers, which shows the necessity of this research. The results of this study will help online sellers of sport products in 
the country to identify some of the causes of fear and worry in the customers in the online purchase process and, to increase the trust and purchase repletion in them by taking appropriate actions while eliminating the fears of the customers.
Given the aforementioned items and the existence of scientific gap in this field, the main purpose of this study is to study the consequences of identity theft in online purchase of sport products from the perspective of physical education students.

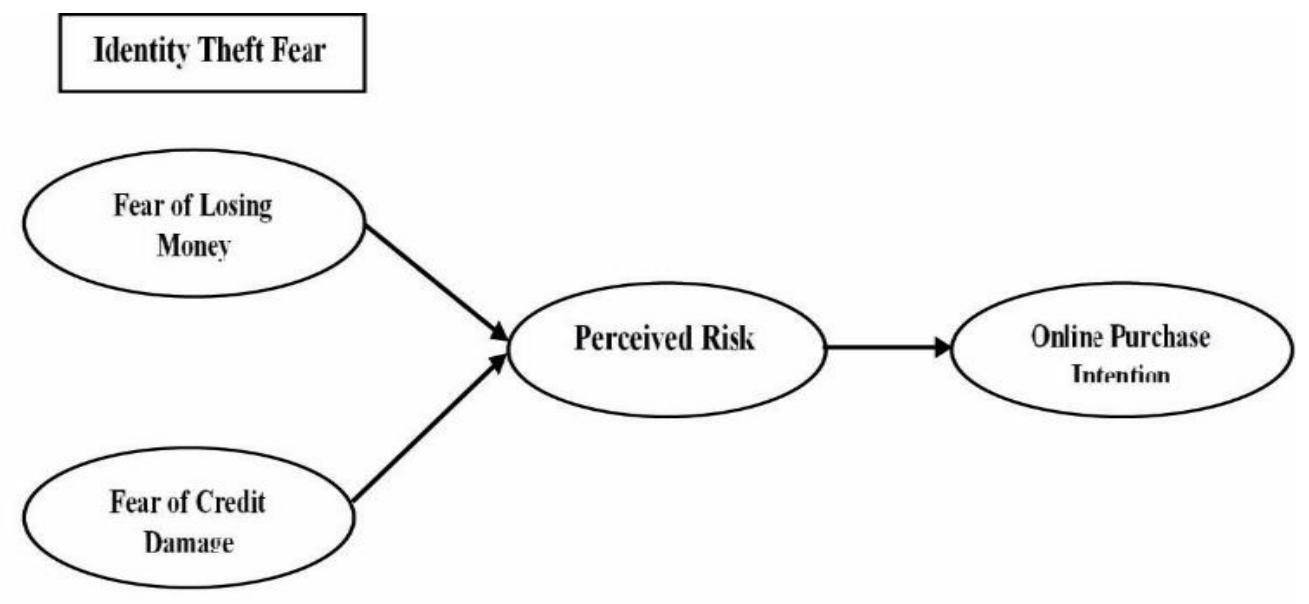

Figure 1. Conceptual Model of Research

\section{MATERIALS AND METHODS}

Research Design. This is a descriptivecorrelational study based on structural equations that has been done in the field.

Participants. The statistical population of the study includes all undergraduate, graduate, postgraduate, and $\mathrm{PhD}$ physical education students of Golestan province universities (government, Islamic Azad, Applied Science and Technology, and Payam Noor) in 2019 with at least two times online purchase experience through sport product sales websites in the past year. Given the inaccuracy of the number of communities with the conditions listed, the sample size was 384 and the available sampling method was used.

Research Tools. Data collection was conducted using the questionnaires of fear of identity theft developed by Hailey et al. (2015), perceived risk in online purchase developed by Chen et al. (2015), and online purchase intention proposed by Chou \& Hsu (2016). The Questionnaire of Identity Theft has 12 items and two components of fear of losing money in the customer (8 items) and fear of credit damage in the customer (4 items). Hayley et al. (2015) have reported the reliability of this questionnaire as 0.94 . The perceived risk questionnaire in online purchase consists of 8 items measured on a 5point Likert scale. Chen et al. (2015) have reported the Cronbach's alpha of 0.87 for this questionnaire. Chou \& Hsu's (2016) Online Purchase Intention Questionnaire also has 4 items with a 5-point Likert scale. These researchers reported the reliability of this questionnaire as 0.91 .

Data Collection Process: To determine the face validity of the research questionnaires, the opinions of 8 sport management professors were used and then, a pilot study (completed by 40 physical education students) was completed to examine the reliability of the questionnaires, and the reliability coefficients of $0.86,0.78$, and 0.81 were obtained using Cronbach's alpha test respectively for the fear of identity theft, perceived risk in online purchase, and customers' online purchase intention questionnaires indicating the stability of the measurement tools. After confirming the validity and reliability of the data collection tools, the necessary coordination with universities of Golestan province was done to reach the research community. Researchers provided the research questionnaire for the subjects by referring to the above mentioned universities and questioning about the experience of online purchase of physical education students 
and ensuring that they had at least 2 times online purchase experience from sports selling websites. Statistical Methods: In this study, descriptive statistics were used to organize, summarize and describe data including frequencies, mean values and standard deviations. For this purpose, SPSS software version 22 and PSL version 3 software were used.

\section{RESULTS}

The demographic characteristics of the research sample have been presented in Table 1. As can be seen in this table, the majority of the sample was in the age group of 20 to 25 years $(n=162)$. The highest frequency about the educational level of the subjects was associated with the bachelor degree (159). Most of the research subjects were male students $(n=201)$. Finally, the results showed that most of the subjects had at least 3 to 4 times online purchase experience over the past year (169 people).

According to Table 2, the mean variables of fear of identity theft, perceived risk and online purchase intention were $3.61,3.68$ and 2.51, respectively.

The results of Kolmogorov-Smirnov test showed that the distribution of data is not normal in the research variables (Table 3) therefore; smart PLS software was used to test the research model using structural equations.

Table 1. Frequency and Frequency Percentage of Subjects by Age, Degree, Gender and Online Purchase Experience

\begin{tabular}{lcc}
\hline Component & Frequency & Cumulative Frequency \\
\hline Age & & \\
Under 20 years & 44 & 11.5 \\
20 to 25 years & 162 & 42.2 \\
26 to 30 years & 99 & 25.8 \\
31 years and older & 79 & 20.6 \\
Degree & & \\
$\quad$ Associate & 105 & 27.3 \\
$\quad$ Bachelor & 159 & 41.4 \\
$\quad$ Master of Art & 107 & 27.9 \\
P.H.D & 13 & 3.4 \\
Gender & & \\
$\quad$ Male & 201 & 52.3 \\
$\quad$ Female & 183 & 47.7 \\
Online Purchase Experience & & \\
At least 2 times & 64 & 16.7 \\
3 to 4 times & 169 & 44 \\
5 times and more & 151 & 39.3 \\
\hline
\end{tabular}

Table 2. Description of the Research Variables

\begin{tabular}{lccc}
\hline Variable & \multicolumn{3}{c}{ Statistics } \\
\cline { 2 - 4 } & Numbers & Average & Standard Deviation \\
\hline Fear of losing money in the customer & 384 & 3.63 & 0.71 \\
Fear of credit damage in the customer & 384 & 3.60 & 0.87 \\
Fear of identity theft & 384 & 3.61 & 0.75 \\
Perceived risk & 384 & 3.68 & 0.73 \\
Online purchase intention & 384 & 2.51 & 0.74 \\
\hline
\end{tabular}

Table 3. Data Distribution Test Results

\begin{tabular}{lcc}
\hline Variable & $\mathbf{Z}$ & P Value \\
\hline Fear of identity theft & 2.71 & 0.001 \\
Perceived risk & 3.89 & 0.001 \\
Online purchase intention & 2.76 & 0.001 \\
\hline
\end{tabular}

In the second part, inferential tests were used to test the hypotheses and research model. To analyze patterns in Structural Equation Approach with partial least squares approach, one must first examine the fitness of the measurement model and then test the research hypotheses in the form of the fitness of the structural model of the research. The fitting of the measurement model is evaluated using three criteria of reliability, convergent validity and divergent validity. The indicators of composite reliability, average variance extracted and factor loadings were used to examine the reliability. If the composite reliability value is greater than 0.7 , the average 
variance extracted is greater than 0.5 , and the factor loadings with the condition of significance of greater than 0.5 , the reliability of the measurement models is confirmed. Considering this and after testing the measurement models and also considering the results presented in
Table 4, the reliability of the research measurement models was estimated as desirable. Also, since the composite reliability values are higher than the baseline criterion (0.7), therefore, research constructs have acceptable convergent validity.

Table 4. Indices of Reliability Assessment of Research Constructs

\begin{tabular}{|c|c|c|c|c|c|}
\hline Item & Factor Load & t-value & AVE & $\mathbf{C R}$ & Cronbach's Alpha \\
\hline Fear of losing money in the customer & & & 0.54 & 0.90 & 0.88 \\
\hline 1 & 0.66 & 18.65 & & & \\
\hline 2 & 0.62 & 12.01 & & & \\
\hline 3 & 0.76 & 44.08 & & & \\
\hline 4 & 0.79 & 40.99 & & & \\
\hline 5 & 0.69 & 17.89 & & & \\
\hline 6 & 0.82 & 41.79 & & & \\
\hline 7 & 0.75 & 29 & & & \\
\hline 8 & 0.78 & 29.37 & & & \\
\hline Fear of credit damage in the customer & & & 0.64 & 0.88 & 0.81 \\
\hline 9 & 0.75 & 28.28 & & & \\
\hline 10 & 0.82 & 48.28 & & & \\
\hline 11 & 0.82 & 32.52 & & & \\
\hline 12 & 0.81 & 28.12 & & & \\
\hline Perceived risk & & & 0.54 & 0.90 & 0.87 \\
\hline 13 & 0.86 & 58.81 & & & \\
\hline 14 & 0.62 & 13.10 & & & \\
\hline 15 & 0.73 & 29.58 & & & \\
\hline 16 & 0.76 & 36.98 & & & \\
\hline 17 & 0.71 & 18.65 & & & \\
\hline 18 & 0.64 & 18.79 & & & \\
\hline 19 & 0.69 & 19.88 & & & \\
\hline 20 & 0.80 & 46.66 & & & \\
\hline Online purchase intention & & & 0.58 & 0.84 & 0.76 \\
\hline 21 & 0.64 & 17.57 & & & \\
\hline 22 & 0.79 & 36.39 & & & \\
\hline 23 & 0.77 & 30.21 & & & \\
\hline 24 & 0.83 & 45.83 & & & \\
\hline
\end{tabular}

For a construct to have acceptable diagnostic or divergent validity, the root mean square of the variance extracted from a construct must be greater than its correlation with other constructs. According to the results of Table 5, it can be stated that the constructs of this study have good diagnostic validity. Also, in structural equation modeling by PLS method for examining the quality or fitting of measurement model or in other words measuring tools, index of Construct Cross Validated Communality is considered. To check this index, the Sum of Squares of Observation for Block and the Sum of Squared Prediction Errors for Block are considered.

Positive values of this index indicate the appropriate quality of the measuring tools. According to the results of Tables 5 and 6, it can be stated that the tools used in the study have good quality.
Communality Index was used in order to evaluate the quality of measuring tools. This index is obtained by dividing the sum of the squares of the prediction errors of the hidden variables by the Sum of Squares of Observation of the hidden variables minus one. Given the positive values of this index for all the hidden variables, it can be stated that the research measurement model has good quality (Table 6).

Table 7 has presented the effects of the research variables on each other. According to this table, fear of losing money has a significant positive effect on perceived risk $(\beta=0.303, t=$ $6.159)$. The effect of fear of credit damage in the customer on the perceived risk was positive and significant $(\beta=0.626, t=13.072)$. Finally, the results showed that the perceived risk effect on consumers' online sport products purchase intention was negative and significant $(\beta=-0.766$, $\mathrm{t}=36.313$ ). 
Table 5. Results of Diagnostic Validity of Research Constructs

\begin{tabular}{lccccc}
\hline Structure & $\mathbf{1}$ & $\mathbf{2}$ & $\mathbf{3}$ & $\mathbf{4}$ \\
\hline Fear of losing money in the customer & 0.74 & & & \\
Fear of credit damage in the customer & 0.79 & 0.80 & & \\
Perceived risk & 0.70 & 0.72 & 0.73 & \\
Online purchase intention & -0.70 & -0.74 & -0.75 & 0.76 \\
\hline
\end{tabular}

Table 6. Results of the Survey on the Construct Cross Validated Communality

\begin{tabular}{lccc}
\hline Structure & SSO & SSE & $\begin{array}{c}1- \\
\text { SSE/SSO }\end{array}$ \\
\hline $\begin{array}{l}\text { Fear of losing money in } \\
\text { the customer }\end{array}$ & 3072 & 1815.10 & 0.40 \\
$\begin{array}{l}\text { Fear of credit damage } \\
\text { in the customer }\end{array}$ & 1536 & 920.60 & 0.40 \\
$\begin{array}{l}\text { Perceived risk } \\
\begin{array}{l}\text { Online purchase } \\
\text { intention }\end{array}\end{array}$ & 3072 & 1884.52 & 0.38 \\
\hline
\end{tabular}

Table 7. Direct Effects of Hidden Variables

\begin{tabular}{lccc}
\hline Predictor & $\begin{array}{c}\mathbf{t} \\
\text { Statistics }\end{array}$ & $\boldsymbol{\beta}$ & $\begin{array}{c}\mathbf{P} \\
\text { Value }\end{array}$ \\
\hline $\begin{array}{l}\text { Fear of losing money in } \\
\text { the customer, perceived } \\
\text { risk }\end{array}$ & 6.159 & 0.303 & 0.001 \\
$\begin{array}{l}\text { Fear of credit damage in } \\
\text { the customer, perceived } \\
\text { risk }\end{array}$ & 13.072 & 0.626 & 0.001 \\
$\begin{array}{l}\text { Perceived risk, online } \\
\text { purchase intention }\end{array}$ & 36.313 & - & \\
\hline
\end{tabular}

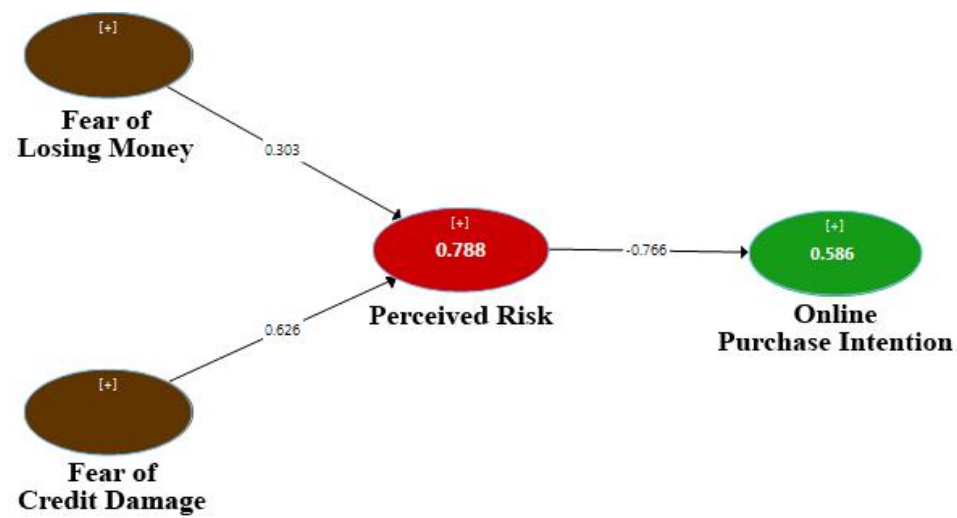

Figure 2. The tested model in the standard estimation mode

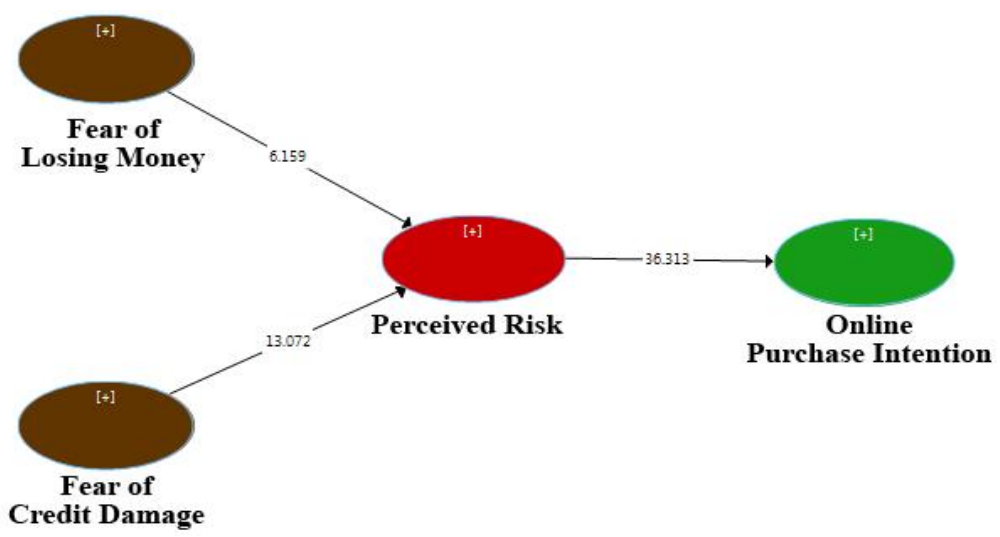

Figure 3. The Tested Model in the Significant Numbers Mode 


\section{DISCUSSION}

The main purpose of this study was to study the consequences of fear of identity theft in online purchase from the perspective of consumers of sport products. The result showed that fear of losing money has a positive and significant effect on perceived risk. This result is consistent with the results obtained by Hille et al. (2015) and Jordan et al. (2018) (12, 21). Nowadays, with the changing needs and demands of sports consumers and costumers as well as increasing the production of sport products, the marketing style of these products has changed and online marketing and selling of sport products to customers has become one of the best practices in this field. This has brought a lot of benefits to both sellers and buyers. The payment method of the consumers for their products and services has changed with the development of the Internet and the shift from online and digital to online sales. Unlike traditional methods, online purchases require customers to provide their personal and financial information to the online seller, which requires special security considerations. Asking for personal and financial information from customers in the online purchase environment can raise serious concerns for customers and increase their perceived risk. Increasing customer concern in online purchase is a factor which can lead to a negative attitude of customers towards this type of purchase. Ariffin et al. (2018) believe that the risk of losing information and funds is one of the strongest predictors of customer behavior in online purchase. Entering customer credit card information or financial accounts into online purchases by customers is always a worrying issue for customers; especially when a customer first buys from an online retailer (4). In such conditions, the privacy of customers in ecommerce is one of the most important demands of customers and, customers are expected to protect their personal information such as name, credit card number, first and second password, or credit card date while presenting them to online sellers. Customer trust in the confidentiality of information provided to online sellers can reduce stress and worry, increase trust and the intention to repurchase customers' sport products. On the other hand, customers' uncertainty about the confidentiality of personal and private information provided to online retailers, the inaccuracy to manage online customer information for sport products, the leak of online customer information intentionally or unintentionally, or the provision of online consumer information to sport products to other sellers can increase the risk perceived by customers and have a negative effect on the consumers' attitude and their purchase intention. According to the theory of resource conservation, fear of losing funds is a stressful factor that causes negative emotions in the customer and increases protective behaviors in the customer (22). According to this principle, funds are an important factor in determining the economic and social status of the customer and, the customer is always trying to avoid threatening factors such as fear of losing money. For example, when a customer does not trust a website and considers it a risk, he or she will avoid giving out personal information and will provide inaccurate or incomplete information.

Findings showed that the effect of fear of credit damage in customer on the perceived risk was positive and significant. This finding is consistent with research findings presented by Hille et al. (2015) and Jordan et al. (2018) (12, 21). The expansion of the electronic business and the development of online stores (websites, Instagram pages, Telegram channels, and sales apps) have provided unique opportunities for sports retailers and their customers in the country (31). Physical education students are one of the most important customers of sport products in online trading; because these customers are a potential source for the development of ecommerce in the country's sports industry, due to the continued use of sport products during their studies and also greater media literacy, however, it should be noted that the development of ecommerce in the country's sports industry requires a secure platform for retailers and customers. Nowadays, as the online business expands, attention to the human, social and legal considerations in this type of business has increased. The most important purpose of these considerations is to maintain the online identity of customers; because online identity is a combination of financial and personal information of the customers and it is an important factor in assessing is the risk perceived by customers and their purchase intention. The most important challenges and concerns for the online business executives in the present era are to protect the material and intellectual property rights of customers, prevent damage to customers' 
identities, and reduce the factors that cause negative experiences such as identity theft in online purchases. Identity theft, along with the consequences such as losing money and time, has other consequences for the customer such as loss of credit, personal and social reputation. This can have a negative impact on customers' daily activities and their quality of life. Customer credit reflects the level of fame, good behavior, faithfulness and customer commitment to the business process. Credit is an important feature of the customer which is gained over time but it can take less than a few minutes. On the other hand, customer credit is an important factor for online retailers; because online retailers categorize their customers based on their credit rating and provide specific services according to their credit. Customers always in the process of traditional and online purchase take care that their credit is not compromised by themselves or others. Victimization of an identity theft in the online purchase process is an issue that can damage the customer's credit (21). For example, misuse of customer financial information by fraudsters or cyber thieves to purchase counterfeit or forbidden products can lead to diminished customer credit and reputation among family, friends, coworkers, and even other sellers. Also, the misuse of virtual thieves from the personal information such as name, surname, contact number or e-mail address to commit unlawful acts such as threatening or deceiving others in order to achieve their personal goals can provide legal problems for the customer while damaging customer credit and reputation. Consequently, customers in online purchases always evaluate the amount of threats that can compromise their credit and make decisions based on the perceived risk of the purchase process or not.

Finally, the results showed that perceived risk had a significant negative effect on the sport products online purchase intention in customers. This result is consistent with the results obtained by Elmosa (2011), Rick et al (2016), Erfin et al (2018) and Jordan et al (2018) (4, 20-22). Today, many factors, such as changes in the needs and requests of sports customers, an increase in the number of manufacturers of sport products, an increase in community interest in sports and recreational activities, and fierce competition among sport product manufacturers have caused the growth and development of the sports industry. In addition to the above, the development of the Internet has also played an important role in the success of the sports industry. Using the Internet to execute the marketing measures of organizations and companies, along with its positive benefits, has negative benefits such as disregarding customers' privacy, increasing customer identity theft, and reducing the customer confidence and trust that results in increased customer perceived risk in online interactions. Many researchers such as Elmosa (2011) and Erfin et al. (2018) believe that the level of risk perceived by customers in online business for reasons such as intangibility of the products, poor product quality, lack of face-toface contact between customer and seller, and fear of losing customers' personal and financial information is more common than traditional business $(4,22)$. Perceived risk arises when the purchase of a product or service by the customer causes potential loss or other negative consequences for the customer. In fact, the consumer's decision to buy products online is the result of their understanding of the purchasing process and its possible outcomes. Also, the perceived risk is the mental evaluation or sentiment in the customer in the uncertainty conditions; the situation in which the customer faces many uncertainties in the various stages of purchasing decision making and at any stage of the purchase decision process may stops the buying behavior. Perceived risk has a direct impact on consumers' attitudes toward online purchase and their attitudes also have a significant effect on online buying behaviors. Accordingly, it can be stated that perceived risk is an important part of customer buying behaviors and the higher perceived risk in the customer leads to lower probability of purchase. However, some researchers such as Rick et al. (2016) believe that having some risk in the online purchase process can be beneficial to customers; this is because the risk allows the customer to search before purchasing and to increase the effectiveness of their purchasing process by gathering information in various ways (20).

\section{CONCLUSION}

Finally, it can be concluded that fear of losing money and fear of credit damage in online purchase can increase perceived risk in the customer. This will have a negative effect on their online purchase intention. In this study, only the effect of identity theft and perceived risk on the sport products purchase intention in physical education students 
was investigated. This can be considered as a limitation of this study. It is suggested to examine other factors that influence the sport products online purchase intention in physical education students such as the quality of sports websites sales, the ethics of these websites and the level of trust in these websites in future research.

\section{APPLICABLE REMARKS}

- Developing specific rules regarding the privacy and security of customers and consumers on the sport products websites.

\section{REFRENCES}

1. Cai Z, Fan X, Du J. Gender and attitudes toward technology use: A meta-analysis. Comput Educ. 2017;105:1-13. doi: 10.1016/j.compedu.2016.11.003

2. Bucko J, Kakalejčík L, Ferencová M, Wright LT. Online shopping: Factors that affect consumer purchasing behaviour. Cogent Bus Manage. 2018;5(1). doi: 10.1080/23311975.2018.1535751

3. Sebastianelli R, Tamimi N. E-tailer website attributes and trust: understanding the role of online reviews. Online Inf Rev. 2018;42(4):506-519. doi: 10.1108/oir-02-2016-0039

4. Kamalul Ariffin S, Mohan T, Goh Y-N. Influence of consumers' perceived risk on consumers' online purchase intention. J Res Int Mark. 2018;12(3):309-327. doi: 10.1108/jrim-11-2017-0100

5. Mohiuddin Babu M, Dey BL. Appraisal of the potential of the growth of e-retailer based on impact of perceived value on trust for online purchases. Strateg Change. 2018;27(5):477-487. doi: 10.1002/jsc.2232

6. Vadera S, Suman SK, Srivastava P. Exploring the behaviour of Indian consumers towards online discounts. Int J Electron Mark Retailing. 2019;10(1). doi: 10.1504/ijemr.2019.10017364

7. Chiu W, Choi H. Consumers' goal-directed behavior of purchasing sportswear products online. Sport Bus Manage Int J. 2018;8(2):118-133. doi: 10.1108/sbm-03-2017-0020

8. Chiu W, Kim T, Won D. Predicting consumers' intention to purchase sporting goods online. Asia Pacific J Mark Log. 2018;30(20):333-351.

9. The Sustainable Role of the E-Trust in the B2C E-Commerce of Vietnam. Sustainabil. 2018;10(2). doi: $10.3390 /$ su 10010291

10. Jain NK, Gajjar H, Shah BJ, Sadh A. E-fulfillment dimensions and its influence on customers in e-tailing: a critical review. Asia Pacific J Mark Log. 2017;29(2):347-369. doi: 10.1108/apjml-11-2015-0167

11. Ngoc Duy Phuong N, Thi Dai g T. Repurchase Intention: The Effect of Service Quality, System Quality, Information Quality, and Customer Satisfaction as Mediating Role: A PLS Approach of M-Commerce Ride Hailing Service in Vietnam. Mark Brand Res. 2018;5(2):78-91. doi: 10.33844/mbr.2018.60463

12. Hille P, Walsh G, Cleveland M. Consumer Fear of Online Identity Theft: Scale Development and Validation. J Int Mark. 2015;30:1-19. doi: 10.1016/j.intmar.2014.10.001

13. Wall* DS. Cybercrime, media and insecurity: The shaping of public perceptions of cybercrime1. Int Rev Law Comput Technol. 2008;22(1-2):45-63. doi: 10.1080/13600860801924907

14. Reisig MD, Pratt TC, Holtfreter K. Perceived Risk of Internet Theft Victimization. Criminal Justice Behav. 2009;36(4):369-384. doi: 10.1177/0093854808329405

15. van Wilsem J. 'Bought it, but Never Got it' Assessing Risk Factors for Online Consumer Fraud Victimization. Eur Soc Rev. 2011;29(2):168-178. doi: 10.1093/esr/jcr053

16. Reyns BW. Online Routines and Identity Theft Victimization. J Res Crime Delinquen. 2011;50(2):216-238. doi: 10.1177/0022427811425539

17. Reyns BW, Henson B, Fisher BS. Being Pursued Online. Criminal Justice Behav. 2011;38(11):1149-1169. doi: 10.1177/0093854811421448

18. Holtfreter K, Reisig MD, Pratt TC, Holtfreter RE. Risky remote purchasing and identity theft victimization among older Internet users. Psychol Crime Law. 2015;21(7):681-698. doi: 10.1080/1068316x.2015.1028545

19. Golladay K, Holtfreter K. The Consequences of Identity Theft Victimization: An Examination of Emotional and Physical Health Outcomes. Victim Offend. 2016;12(5):741-760. doi: 10.1080/15564886.2016.1177766

20. Riek M, Bohme R, Moore T. Measuring the Influence of Perceived Cybercrime Risk on Online Service Avoidance. IEEE Transact Depend Secure Comput. 2016;13(2):261-273. doi: 10.1109/tdsc.2015.2410795

21. Jordan G, Leskovar R, Marič M. Impact of Fear of Identity Theft and Perceived Risk on Online Purchase Intention. Organizacija. 2018;51(2):146-155. doi: 10.2478/orga-2018-0007 
22. Almousa M. Perceived risk in apparel online shopping: a multi dimensional perspective. Canada Soc Sci. 2011;7(2):23-31.

23. Laroche M, Yang Z, McDougall GHG, Bergeron J. Internet versus bricks-and-mortar retailers: An investigation into intangibility and its consequences. J Retail. 2005;81(4):251-267. doi: 10.1016/j.jretai.2004.11.002

24. Nepomuceno MV, Laroche M, Richard M-O. How to reduce perceived risk when buying online: The interactions between intangibility, product knowledge, brand familiarity, privacy and security concerns. J Retail Consume Servic. 2014;21(4):619-629. doi: 10.1016/j.jretconser.2013.11.006

25. Kim J, Lennon SJ. Effects of reputation and website quality on online consumers' emotion, perceived risk and purchase intention. J Res Interact Mark. 2013;7(1):33-56. doi: 10.1108/17505931311316734

26. Yu S. Does fear of victimization deter online shopping? J Financ Crime. 2018;25(3):770-783. doi: 10.1108/jfc05-2017-0038

27. Han MC, Kim Y. Why Consumers Hesitate to Shop Online: Perceived Risk and Product Involvement on Taobao.com. J Promot Manage. 2016;23(1):24-44. doi: 10.1080/10496491.2016.1251530

28. Saleh Z. The impact of identity theft on perceived security and trusting E-commerce. $J$ Internet Bank Commer. 1970;18(2):1-11.

29. Reisig MD, Holtfreter K. Shopping fraud victimization among the elderly. J Financ Crime. 2013;20(3):324-337. doi: 10.1108/jfc-03-2013-0014

30. Brands J, van Wilsem J. Connected and fearful? Exploring fear of online financial crime, Internet behaviour and their relationship. Eur J Criminol. 2019;16(6):1-22. doi: 10.1177/1477370819839619

31. Benesbordi A, Nazari Torshizi A. Investigating the online shopping style of sport products from virtual networks and online stores. Sport Manage Stud. 2019;10(52):117-136. 